\title{
Germline development and seed set of metallophyte Biscutella laevigata L. (Brassicaceae).
}

\author{
Monika Kwiatkowska ${ }^{1}$, Karolina Kłosowska ${ }^{1}$, and Ewa Kurczyńska ${ }^{2}$ \\ ${ }^{1}$ Jagiellonian University in Krakow \\ ${ }^{2}$ University of Silesia Institute of Biology Biotechnology and Environmental Protection
}

July 16, 2020

\begin{abstract}
The costs of Biscutella laevigata adaptation, a facultative metallophyte, to an environment polluted with heavy metals were established by analyzing the differences in embryological processes between plants from two populations in Southern Poland (a mountain, in the Tatra Mountains and calamine, in Bolesław). Disturbances in male and female lineage development and degeneration processes occurred in the anthers and ovules of plants from both populations, but with a higher frequency in the calamine population where A part of stamens/anthers and ovules in flowers were in a stage of degenertion. which could be interpreted as a strategy to save resources limited by the environment. The distribution of high-esterified homogalacturonan detected by LM20 antibody in the cell walls of embryos from the calamine population could be part of a resistance/defense system. The results from both populations indicate that B. laevigata has already developed adaptation/tolerance, enabling maintenance of the calamine population over time. Tolerant species could be an important source for revitalization and/or phytoremediation of polluted environments.
\end{abstract}

\section{Introduction:}

Calamine flora, colonizing areas polluted with heavy metals, is an excellent model for studying the microevolution of species/populations, speciation and metallophyte origin, the genetic structure of populations (Hildebrandt et al. 2006; Kuta et al. 2012; Słomka et al. 2011; Wąsowicz et al. 2014; Wierzbicka and Rostański 2002), physiological adaptation to harsh conditions (Słomka et al. 2008), colonization and seed banks (Grodzińska et al. 2001), as well as the biology of reproduction (Bothe \& Słomka 2017; Izmaiłow et al. 2015).

Embryological characteristics are important traits to evaluate metallophyte adaptation/tolerance. Impaired sexual reproduction of plants colonizing polluted areas leading to reduced plant fertility and seed set, could be considered as costs of adaptation. The more disturbances in the reproductive processes and degenerations, the lower the tolerance. This can be inferred from published studies on the reproduction of angiosperm's taxa representing different metallophyte status from Polish post-industrial areas: e.g. Armeria maritima , Capsella bursa-pastoris , Cardaminopsis arenosa ,Cirsium arvense, Chondrilla luncea , Echium vulgare, Vicia cracca or Viola tricolor and other violets (Czapik 2002; Izmaiłow 2000; Izmaiłow \& Biskup 2003 ; Izmaiłow et al. 2015; Kościńska-Pająk 2000; Kwiatkowska \& Izmaiłow 2014; Siuta et al. 2005; Słomka et al. 2012, 2017, 2018).

There is a lack of embryological data on B. laevigata, a facultative metallophyte (plants can grow in metalenriched soil/substrate and also in unpolluted areas) which is a member of European calamine flora. The species has been widely studied, including its distribution, taxonomic and systematic position, karyotype analysis, ploidy level (diploid $v s$ tetraploid), genetic diversity and genetic structure of European populations (e.g. Manton 1937; Olowokudejo 1992; Tremetsberger et al. 2002). 
In Poland (Eastern Europe), B. laevigata (2n=18) (Babs-Kostecka et al. 2014; Skalińska 1950), a glacial relict, occurs in the Tatra Mountains and on over 100-year-old $\mathrm{Zn}-\mathrm{Pb}$ waste-heap in Bolesław, an isolated location in an anthropogenic, postindustrial site with elevated concentrations of heavy metals. Recently, a new location on a lowland in Central Poland has been discovered (Przemyski \& Piwowarczyk 2012). Until now, the studies on Polish populations of B. laevigata have focused on: mycorrhizal status, adaptation and tolerance to heavy metal stress, concentrations of heavy metals in plant organs and the genetic structure of populations (e.g. Antosiewicz 1995; Babst-Kostecka et al. 2014; Godzik 1993; Gołda \& Wojciechowska 1979; Orłowska et al. 2002; Wąsowicz et al. 2014; Wierzbicka \& Pielichowska 2004; Wierzbicka et al. 2017). B. laevigata was also used for restoriation in post-industrial areas (Rostański 2014).

Plants that live in heavy metal-enriched habitats take metal ions from the rhizosphere and transport them into plant cell/tissue/organs. In cytosol, free metals are harmful as they cause oxidative stress or damage to organelles. To deal with this negative impact, plants have to bind metals and detoxify them. In the evolution of adaptation, plants have developed two main strategies (cell level) that allow them to survive in such extreme conditions: (1) metal accumulation, in some species hyperaccumulation, and (2) metal exclusion (e.g. Baker 1981; Hall 2002; Prasad 2004). The cell wall is the main structure that can be actively modified under internal or external factors/stress and plays a crucial role in defense strategies. In the metal exclusion strategy when metals are taken from the environment, transported through the apoplast, the cell wall is the barrier that stops metals entering the cell symplast. In metal accumulation strategy, metals entering the cell are sequestrated in the cell wall. In particular, homogalacturonan, a major component of the plant primary walls plays a crucial role in the binding and accumulation of heavy metals in the cell wall. However, other compounds, such as other polysaccharides, proteins, amino acids or phenolics, can also take part in metal detoxification (le Gall et al. 2015; Krzesłowska 2011).

The aim of this study was to (1) estimate the frequency of developmental disturbances and degenerations in male and female lineages ofBiscutella laevigata as the costs of adaptation/tolerance to areas polluted with heavy metal; (2) how the un/low- and high-methyl-esterified homogalacturonan (HG) recognized by LM19 and LM20 antibodies, respectively, are distributed in the cell wall of mature embryos as a defense response to toxic metals.

\section{Materials and Methods:}

Specimens of Biscutella laevigata L. were collected from two isolated sites: (1) Jaworzynka Valley in the West Tatra Mts. (mountain population), the control population growing on Humic-Rendzic Leptosols composed of Triasic dolomite, located at 1100 m. a.s.l. (Szarek-Łukaszewska \& Niklińska 2002, after Skiba 1983). (2) Over 100-years old zinc-lead mine spoils in Bolesław (calamine population) where calamine flora has evolved. The spoil is located in Upper Silesia, the most industrial region in South Poland, rich in zinc and lead ores (zinc blende and lead-glance with a high content of silver and secondary minerals). Exploitation of ores using open-cast technology ceased at the beginning of the $20^{\text {th }}$ century and the spoil is overgrown with grassland as a result of spontaneous succession. The substrate contains high concentrations of heavy metals, Zn (49700 $\mathrm{mg} / \mathrm{kg}), \mathrm{Pb}(2830 \mathrm{mg} / \mathrm{kg}), \mathrm{Mn}(1810 \mathrm{mg} / \mathrm{kg}), \mathrm{Fe}(47800 \mathrm{mg} / \mathrm{kg}), \mathrm{Cd}(154 \mathrm{mg} / \mathrm{kg})$ (Szarek-Łukaszewska \& Niklińska 2002).

Flower buds, flowers, fruits (siliculas) at different developmental stages were fixed in situ in FAA (mixture of acetic acid, formaldehyde, ethyl alcohol $70 \% ; 4: 6: 90 \mathrm{v} / \mathrm{v}$ ) for 24 hours, stored in $70 \%$ ethanol at $4{ }^{\circ} \mathrm{C}$ until used.

Pollen viability was assessed with Alexander dye (Alexander 1969).

For paraffin sections, samples/materials were dehydrated in an increasing ethanol series; $100 \%$ ethanol was removed by chloroform (in proportions $3: 1 ; 1: 1 ; 1: 3 ; 0: 1$ with paraffin in $57^{\circ} \mathrm{C}$ ). Then, material was embedded in paraffin blocks and sectioned at $10 \mu \mathrm{m}$ on a rotary microtome (Adamas Instrumenten BV, HM 340E), sections were stained with Heidenhain's hematoxylin (FLUKA) combined with alcian blue (FLUKA) and mounted in Entellane (Aldrich). 
A clearing technique using methyl salicylate was used for visualization of male and female gametophytes in anthers and ovules, respectively. After dehydration in an ethanol series, material was cleared in a mixture of $100 \%$ ethanol and methyl salicylate (Sigma-Aldrich) in proportions $3: 1 ; 1: 1 ; 1: 3$, in pure methyl salicylate and observed in a drop of methyl salicylate with Nomarski differential interference contrast (DIC) optics (Young et al., 1979, slightly modified).

For detection of metals in flowers and seeds dithizone staining was applied (Seregin and Kozhevnikova 2011).

Immunohistochemical detection of pectin distribution in cell walls of embryo tissues, using primary antibodies for low- and high-esterified homogalacturonan, LM19 and LM20, was preceded according to the protocol of Milewska-Hendel et al. (2017). Slides were mounted in a Fluoromount (Sigma-Aldrich) antifade medium. Negative control was performed for each probe by incubated with a blocking buffer instead of primary antibodies and revealed the absence of any signals. Observations and documentation were carried out using a Nikon Eclipse Ni-U microscope equipped with a Nikon Digital DS-Fi1-U3 camera with corresponding software (Nikon, Tokyo, Japan). Immunohistochemical analyses were performed on at least three samples from analysed species from each studied area. The photos are representative of the obtained results.

A total of 30 randomly taken specimens were analyzed. For female lineage observation over 1300 ovules were studied at various developmental stages: archesporial cells, megasporocytes, megasporogenesis, megagametogenesis, embryogenesis, mature embryos (for all techniques); additionally for male lineage observation 130 flower buds from very small to just before anthesis were analyzed in the following stages: archesporial tissue, microsporocytes, microsporogenesis, microgametogenesis, mature pollen grains; for pollen viability over 4000 mature pollen grains were counted from both sites ( 5 flowers from each 10 randomly chosen plants). Studies were carried out for two growing seasons. The authors did not observe any strong weather conditions (e.g. drought, floods) that could be an impact on the results.

Statistic chi-square test was used in Microsoft Office Excel 2010 to find significant differences between populations.

Results:

I. Embryological processes in mountain plants versus plants from calamine population - disturbances and degenerations

\section{Plants from Tatra mountain population}

Developmental processes in the male and female lineages proceeded, in a high percentage, regularly. Threecelled mature pollen developing in tetrasporangiate anthers from microsporocytes after meiosis and simultaneous cytokinesis was highly viable, reaching $98 \%$ of the viability (Tab. 1; Fig. 1a, b). In the ovary two campylotropous, tenuicellular and bitegnic ovules underwent simultaneous development. In $95 \%$ of analyzed ovules the archesporial cell in the nucellus develops in the megasporocyte and linear tetrad forms after meiotic divisions (Fig. 1c-e). T-shaped tetrads were also observed. Monosporic female gametophyte (embryo $\mathrm{sac}$ ) develops from the chalazal megaspore according to the Polygonum type (Fig. 1e). In mature 7-celled embryo sac at the micropylar region an egg apparatus with egg cell and two synergids is located, in central cell secondary nucleus is forming after fusion of two polar nuclei, at chalazal pole three short-living antipodals (Fig. 1f). After fertilization the embryo develops according to the Onagrad type and whole endosperm is consumed during embryogenesis (Fig. 1g). In ca $8 \%$ of young ovules additional embryo sac underwent development (Tab. 2). It might originated from additional archesporial cell or rather from the developing sub-chalazal megaspore of the same tetrad (Fig. 1h). These additional embryo sacs can reach maturity (Fig. 1i). The most frequently additional, sub-chalazal originated embryo sacs were observed at early stage of development.

Degenerations during megasporogenesis, embryo sac development and in mature embryo sac occurred with low frequency $(7 \%)$ in analyzed flower buds. Shortening of mature embryo sacs were found in $4 \%$ of ovules, aging of mature embryo sacs without fertilization and lack of embryo sac in $7 \%$ of ovules, disturbed embryogenesis in $5 \%$ of seeds. Degenerations of whole flower buds and whole ovules both in flowers and developing 
seeds were observed with frequency of $7 \%$ (Tab. 2).

In $41 \%$ of analyzed fruits 2 -seeds were formed, in $21 \%$ only one-seed developed, $38 \%$ fruits had no seeds.

Plants from Bolestaw calamine population

In metallicolous population in the male lineage, degenerations of microsporocytes, tetrads of microspores, microspores, tapetum cells (microsporogenesis) and pollen grains at all stages of their development (microgametogenesis) were found in $40 \%$ of analyzed flower buds (only a part of anthers were disrupted) leading to decreasing the pollen production by the plant and to reduction of viable pollen grains (87\%) (Tab. 1; Fig. $2 \mathrm{a}-\mathrm{d}$,$) .$

Developmental disturbances and necrotic processes in megasporogenesis were found only in $2 \%$ of analyzed flower buds. During female gametophyte development and at the stage of mature embryo sac, degenerations were observed in $12 \%$ of ovules (Tab. 2). They included degenerations of whole female gametophytes at different stages of their development or degenerations of single cells as egg cells, synergids. In some ovaries development of two ovules was not synchronous. Ovules inhibited in their development were eliminated from further development. In $25 \%$ of analyzed ovules strong shortening of mature embryo sac was observed, of which almost half degenerated (Fig. 2e, f). In some ovules (7\%) female gametophyte were not formed. All these degenerations were usually observed only in one of two ovules in the ovary. In $10 \%$ of ovules aging, mature, unfertilized embryo sac started to degenerate (Fig. 2g). Majority of embryos developed regularly according to the Onagrad type, degenerations occurred in $15 \%$ of analyzed ovules. They included especially degenerations at young stages (at zygote/proembryo stages). In late stages of embryogenesis only few groups of degenerated cells were observed in the embryo tissues.

Degenerations of whole flower buds were very low (2\%), in some pistils a part of stigma cells degenerated (Fig. 2h), degenerations of ovules in flowers and young siliculas (Fig. 2i) were found in $4 \%$.

In $55 \%$ of fruits two-seed siliculas developed, one seed in 30\%, empty siliculas in $15 \%$ of analyzed fruits (Fig. 2i-1; Tab. 3).

Dithizone staining showed the presence (red coloration) of heavy metals in flowers and fruits in specimens from calamine population (Fig. 2m, n).

II. Distribution of un/low- and high-methyl-esterified HG in cell walls

Low-esterified HG, detected by LM19 antibody were distributed in the same pattern in cell walls of embryos in plants from mountain and calamine populations (Fig. 3a-c). The distribution of high-esterified HG, detected by LM20 antibody in cell walls of embryos differed between populations. High-esterified HG were present only in embryos from the calamine population, and their distribution was not continuous in the cell wall. They were identified locally, as spots (Fig. 3d-f).

III. Costs of tolerance measured by reduced plant fertility

In the male lineage, pollen viability was reduced to $87 \%$ and the differences between calamine and mountain populations were statistically significant. Also degenerations in anthers during development occurred with higher frequency in calamine population (39\% vs 19\%) (Tab. 1).

In the female lineage, the frequency of degenerations in flowers, ovules at different stages of female gametophyte development in plants from calamine population exceeded the frequency of these processes in plants from mountain population (14\% vs $7 \%$ ) and the differences were statistically significant (Tab. 2).

The number of seeds in the silicula was variable in both populations. In calamine population formation of normal two-seed siliculas was higher (55\%) than in plants from mountain population (41\%) and the differences were statistically significant between two populations (Tab. 3).

Discussion: 
Analysis of the embryological traits of Biscutella laevigata , a facultative metallophyte, from heap and mountain populations clearly indicates that the costs of tolerance, measured as the success of sexual reproduction, are not high. Plants colonizing the Bolesław calamine heap develop fruits and seeds to an amount allowing the population to be maintained. Plants accumulated metals in their generative organs (flowers), as was demonstrated by histochemical tests, but they developed defense mechanisms, including the biosynthesis of high-esterified homogalacturonans in the cell wall of embryos. The fraction of pectins is probably involved in the reactions of resistance to metals that retain noxious ions in the apoplast of the new generation (embryo). The cell wall, apoplastic compartment, is a well-known extracellular site involved in the detoxification of metal ions harmful to the cell (le Gall et al. 2015; Krzesłowska 2011).

Disturbances in female and male lineages and degeneration processes occurred with higher frequency in plants growing in the calamine population than in the mountain population. Are these changes only a result of the heavy metal presence, or are they also influenced by other factors? On post-industrial areas, secondary enriched with heavy metals by industrial and mining activities, other factors might influence plant physiological processes and reproduction, including: very low nutrient content, skeletal soil structure with low water retention, strong insolation and eolian erosion resulting from strong winds in open dump sites. To survive these harsh environmental conditions, plants must overcome heavy metal, drought, low/high temperatures, nutrient and salt stresses. Species spontaneously colonizing contaminated sites undergo microevolutionary processes, which enable the survival of individuals adapted to local conditions and the beneficial traits / genes to be passed on to their offspring (Wierzbicka \& Rostański 2002; Wierzbicka et al. 2017).

The frequency of disturbances and degenerations in male and female lineages are good indicators of the costs of tolerance/adaptation (Izmaiłow et al. 2015). The flowering plant life cycle is divided into haploid and diploid generations. The haploid phase, extremely reduced and consisting of only a few cells, is dependent on the sporophytic generation for nutrition and protection (Ge et al. 2010). All processes of sexual reproduction (male and female meiosis, gametophyte development, double fertilization and embryo development) are not only dependent on genotype or species, but also on external conditions. The taxon in an early stage of colonization is poorly adapted to environmental stress and disturbances, with degenerations in particular being much more frequent than in metallophytes, which are better adapted to harsh conditions. However, several traits related to the biology of reproduction are conservative, regardless of the environmental factors, e.g. type of cytokinesis, pattern of embryo sac development, embryogenesis model or type of seeds (Izmaiłow et al. 2015; Siwek 2007). From the research conducted on B. laevigata, it follows that the simultaneous type of cytokinesis in anthers, three-celled pollen grains, a monosporic embryo sac developing according to the Polygonum type, the Onagrad type of embryo development, nucellar endosperm, and additional embryo sacs in an ovule, were conservative and the same in plants from the mountain and calamine populations. Necrosis and degenerations found in male and female lineages of B. laevigata from the calamine population could be a result of the same evolutionary strategies that were observed in Armeria maritima s.l., another metallophyte of calamine flora (author's observations, unpublished). These processes reduced the pollen viability and seed set. This was also reflected in the frequency of one-seed siliculas. Selective abortion of seeds is a well-known phenomenon in flowering plants. Developing embryos compete and the weakest are aborted. Moreover, the mother plant may set the level of abortion. The abortion of viable embryos leads to higher offspring quality (de Jong \& Klinghamer 2005). We observed in B. laevigata from the calamine population that some gametophytes (female or male) were also excluded from further development and this could lead to better quality of offspring. The presence of unfertilized mature and properly developed female gametophytes at a stage of aging indicates that the reduced fertility of $B$. laevigata, a self-incompatible species (Leducq et al. 2010; Young et al. 2012), might also result from a lack or insufficient number of pollinators.

Quantitative analysis of metals in specimens from metallicolous populations indicates that they are present in generative organs (flowers and fruits), although metals are generally at a much lower level than in vegetative tissues (e.g. Dhiman et al. 2017; Godzik 1993; Mesjasz-Przybyłowicz et al. 2001). In plants from metallicolous sites, metal uptake, distribution and deposition depend on the strategy that plants have evolved. Specimens could accumulate (even hyperaccumulate) metals in the aerial part or exclude them. Metals are 
quickly detoxified by binding with many molecules (e.g. phytochelatines), localized in vacuoles, sequestered in cell walls, deposited in aging leaves or in trichomes, for the protection of organelles and biochemical reactions against free toxic heavy metal ions in cytosol (Antonovics 1971; Ernst et al. 1992; Prasad 2004).

The reproductive processes depend on how the plant fights ionic stress and other extreme conditions, how much energy and resources it devotes to it and how much energy remains to produce flowers, fruits and seeds. Metal ions, along with water, mineral salts and assimilates, are transported to generative structures, where they might directly affect the haploid cells of gametophyte phase or embryos, even when they are present in small doses (Kranner and Colville 2011; Sperotto et al. 2014; Walker \& Waters 2011). The gametophyte phase of ontogenesis is more sensitive to abiotic stress (metal, salt, hot/cold temperature) than the sporophyte, therefore adaptations develop first on the sporophyte level, and then in the cells of the germlines (Hedhly 2011; Kazan and Lyons 2016; Kwiatkowska \& Izmaiłow 2014; Słomka et al. 2012; Sun et al. 2004; Zinn et al. 2010).

\section{Conclusion}

1. Biscutella laevigata colonizing the calamine population in Boleslaw developed adaptation strategies to the site polluted with heavy metals, as indicated by features related to the biology of reproduction: (a) Success in sexual reproduction enabling maintenance of the calamine population over time, despite the disturbances and degeneration processes observed in male and female lineages development; (b) Degeneration of parts of stamens/anthers and one ovule in two-ovule ovaries as an adaptation to limited resources and extreme conditions/stress; (c) Shortening of female gametophytes as a strategy to accelerate entry into the generative phase; (d) Change in the chemistry of cell walls in embryonic cells as the mechanism of metal detoxification.

2. The reduced fertility of plants from contaminated areas does not have to result only from the negative impact of high concentrations of metals in the soil, but also from other factors, as demonstrated by present studies on Biscutella laevigata. It is necessary to interpret the results with great caution while drawing conclusions.

3. Our studies indicate that Ecological Embryology, a term introduced by Professor Romana Czapik in 2002 , is a very good tool for studying the level of plant adaptation to extreme environments. Tolerant species/taxa, reproducing sexually on contaminated populations, could be useful for revitalization and/or phytoremediation, a biological method for cleaning up the environment.

\section{Acknowledgments:}

We would like to thank the Professor Elżbieta Kuta from the Institute of Botany of the Jagiellonian University for her valuable comments and discussions about the results of the work and during writing the manuscript. We thank also to Robert Gawecki from the Department of Cell Biology of the Silesian University for his technical assistance during analysis of cell wall composition.

This work was supported by statutory research funds from the Department of Plant Cytology and Embryology, Faculty of Biology, Jagiellonian University in Cracow and from the Department of Cell Biology, Silesian University in Katowice.

This research did not receive any specific grant from funding agencies in the public, commercial, or not-forprofit sectors.

\section{Author Contributions:}

All Authors make substantial contributions to the manuscript: MK, KK, EUK study conception and design; MK, KK material collection; MK, KK methodology, analysis and interpretation of data; MK acquisition of data, documentation; MK, EUK analysis and interpretation of immunohistochemical data; MK drafting of manuscript; EUK contribution to interpretation of data, critical revision of the manuscript; MK, EUK funding Acquisition.

Conflicts of Interest: 
The authors declare no conflict of interest.

References:

Alexander M.P. (1969) Differential Staining of Aborted and Nonaborted Pollen. Stain

Technology , $44,117-122$.

Antonovics J., Bradshaw A.D., Turner R. (1971) Heavy metal tolerance in plants in: Gragg

J.B. (Ed.). Advences in ecological research , 7, Academic Press, London and New York. pp: 1-

85.

Antosiewicz D.M. (1995) The relationships between constitutional and inducible Pb-tolerance and tolerance to mineral deficits inBiscutella laevigata and Silene inflata. Environmental and Experimental Botany , 35(1) , 55-69.

Babst-Kostecka A., Parisod Ch., Godé C., Vollenweider P., Pauwels M. (2014) Patterns of genetic divergence among populations of the pseudometallophyte Biscutella laevigata from southern Poland.Plant and Soil, $383,245-256$.

Baker A.J.M. (1981) Accumulators and excluders - strategies in the response of plants to heavy metals. Journal of Plant Nutrition ,3, 643-654.

Bothe H., Słomka A. ( 2017) Divergent biology of facultative heavy metal plants. Journal of Plant Physiology , $29,45-61$.

Czapik R. [Ed.] (2002) Embryological and cytological variability of plants in polluted environment. Polish Botanical Studies ,15 , Szafer Institute of Botany. Polish Academy of Science: pp. 58.

Dhiman S.S., Zhao X., Li J., Kim D., Kalia V.C., Kim I. et al. (2017) Metal accumulation by sunflower (Helianthus annuus L.) and the efficacy of its biomass in enzymatic saccharification. PLoS ONE ,12(4), e0175845. https://doi.org/10.1371/ journal.pone.0175845.

Ernst W.H.O., Verkleij J.A.C., Schat H. (1992) Metal tolerance in plants. Acta Botanica Neerlandica, 41(3) , 229-248.

Le Gall H., Philippe F., Domon J.M., et al. (2015) Cell wall metabolism in response to abiotic stress. Plants , $4,112-166$.

Ge X., Chang F., Ma H. (2010) Signaling and Transcriptional Control Review of Reproductive Development in Arabidopsis. Current Biology , 20 , 988-997.

Godzik B. (1993) Heavy metals content in plants from zinc dumps and reference areas. Polish Botanical Studies , 5 , 113-132.

Gołda E., Wojciechowska B. (1979) The analysis of zinc compound contents in the tissues of Biscutella laevigata L. Acta Biologica ,297, 105-111.

Grodzińska K., Korzeniak U., Szarek-Łukaszewska G., Godzik B. (2001) Colonization of zinc mine spoil in southern Poland - preliminary studies on vegetation, seed rain and seed bank. Fragmenta Floristica et Geobotanica, 45, 123-145.

Hall J.L. (2002) Cellular mechanisms for heavy metal detoxification and tolerance. Journal of Experimental Bot any,53(366) , 1-11.

Hedhly A. (2011) Sensitivity of flowering plant gametophytes to temperature fluctuations. Environmental and Experimental Botany ,74, 9-16. 
Hildebrandt U., Hoef-Emden K., Backhausen S., Bothe H., Bożek M., Siuta A., Kuta E. (2006) The rare, endemic zinc violets of Central Europe originate from Viola lutea Huds. Plant Systematic and Evolution, $257,205-222$.

Izmaiłow R. (2000) Reproduction of Vicia caracca L. in the polluted environment of the Legnica-Głogów Copper Basin (Poland).Acta Biologica Cracoviensia Series Botanica , 42(2) , 125-133.

Izmaiłow R., Biskup A. (2003) Reproduction of Echium vulgare L. (Boraginaceae) at contaminated sites. Acta Biologica Cracoviensia Series Botanica , 45(1) , 69-75.

Izmaiłow R., Pajak M., Kwiatkowska M., Musiał K. (2015) Wpływ metali cieżkich na procesy reprodukcyjne roślin. W: Wierzbicka M. (Red)Ekotoksykologia: rośliny, gleby, metale. Wydawnictwa Uniwersytetu Warszawskiego WUW. Warszawa: pp. 96-116. In polish .

De Jong T., Klinkhamer P., (2005) Selective embryo abortion. In:Evolutionary ecology of plant reproductive strategies. Cambridge University Press: pp. 215-228.

Kazan K., Lyons R. (2016) The link between flowering time and stress tolerance. Journal of Experimental Botany , 67(1) , 47-60.

Kościńska-Pajak M. (2000) Microspores and pollen grain in triploid Chondrilla jucea L. from unpolluted and polluted areas.Acta Biologica Cracoviensia Series Botanica , 42(2) , 135-140.

Kranner I., Colville L. (2011) Metals and seeds: Biochemical and molecular implications and their significance for seed germination.Environmental and Experimental Botany , 72, 93-105.

Krzesłowska M. (2011) The cell wall in plant cell response to trace metals: polysaccharide remodeling and its role in defense strategy.Acta Physiologiae Plantarum , 33 , 35-51.

Kuta E., Bohdanowicz J., Słomka A., Pilarska 'M., Bothe H. (2012) Floral structure and pollen morphology of two zinc violets (Viola lutea ssp. calaminaria and V. luteassp. westfalica) indicate their taxonomic affinity to Viola lutea. Plant Systematic and Evolution, 298 , 445-455.

Kwiatkowska M., Izmaiłow R. (2014) Ovule, female gametophyte and embryo are more sensitive to heavy metal pollution than anthers and pollen ofCardaminopsis arenosa (L.), a member of calamine flora.Acta Biologica Cracoviensia Series Botanica, 56(1), 128-137.

Leducq J.B., Gosset C.Ch., Poiret M., Hendoux F., Vekemans X., Billiar S. (2010) An experimental study of the S-Allee effect in the self-incompatible plant Biscutella neustriaca . Conservation Genetics , 11 , 497-508.

Manton I. (1937) The problem of Biscutella laevigata L. II. The evidence from meiosis. Annals of Botany, $1,439-462$.

Mesjasz-Przybyłowicz J., Grodzińska K., Przybyłowicz W.J., Godzik B., Szarek-Łukaszewska G. (2001) Nuclear microprobe studies of elemental distribution in seeds of Biscutella laevigata L. from zinc wastes in Olkusz, Poland. Nuclear Instrument and Methods in Physics Research Section B , 181 , 634-639.

Milewska-Hendel A., Baczewska A.H., Sala K., Dmuchowska W., Bragoszewska P., Gozdowski D., et al. (2017) Quantitative and qualitative characteristics of cell wall components and prenyl lipids in the leaves of Tilia $\mathrm{x}$ euchlora trees growing under salt stress. PLos ONE ,12(2) , eo172682. Doi:10.1371/journal.pone.0172682.

Prasad M.N.V. (Ed.) (2004) Heavy metal stress in plants. From biomolecules to ecosystems . Springer-Verlag Berlin Heidelberg: pp 462.

Przemyski A., Piwowarczyk R. (2012) Biscutella laevigata L. in the polish uplands - new data on its distribution on Nida Basin.Botanica Steciana, 16 , 21-29.

Olowokudejo J.D. (1992) Taxonomic significance of leaf indumentums characteristics of the genus Biscutella (Cruciferae). Folia Geobotanica et Phytotaxonomica , 27, 401-417. 
Orłowska E., Zubek Sz., Jurkiewicz A., Szarek-Łukaszewska G., Turnau K. (2002) Influence of restoration on arbuscular mycorrhiza ofBiscutella laevigata L. (Brassicaceae) and Plantago lanceolata L. (Plantaginaceae) from calamine spoil mounds. Mycorrhiza , 12, 53-60.

Rostański A. (2014) Intentional introduction of Biscutella laevigata L. on the post-flotation lead-zinc ore spoil heap in Piekary Ślaskie (Upper Silesia, Southern Poland). Environmental ReS ,2(3) , 24-32.

Seregin I.V., Kozhevnikova A.D. (2011) Histochemical Methods for Detection of Heavy Metals and Strontium in the Tissues of Higher Plant.Russian Journal of Plant Physiology , 58(4) , 721-727.

Siuta A., Bożek M., Jedrzejczyk M., Rostański A., Kuta E. (2005) Is the blue zinc violet (Viola guestphalica Nauenb.) a taxon of hybrid origin? Evidence from embryology. Acta Biologica Cracoviensia Series Botanica , 47(1), 237-245.

Siwek M. (2007) Embryological processes in Armeria maritima(Mill.) Willd (Plumbaginaceae), Cardaminopsis arenosa (L.) Hayek (Brassicaceae) and Medicago lupulina L. (Fabaceae) in postindustrial areas. Thesis. Jagiellonian Uniwersity. Cracow. In polish .

Skalińska M. (1950) Studies in chromosome numbers of Polish Angiosperms.

Acta

Societtis Botanicorum Poloniae, 20 , 45-68.

Słomka A., Jedrzejczyk-Korycińska M., Rostański A., Karcz J., Kawalec P., Kuta E. (2012) Heavy metals in soil affect reproductive processes more than morphological characters in Viola tricolor .Environmental and Experimental Botany , 75 , 204-211.

Słomka A., Kwiatkowska M., Bohdanowicz J., Shuka L., Jedrzejczyk-Korycińska M., Borucki W., Kuta E. (2017) Insight into "serpentine syndrome" of Albanian, endemic violets (Viola L., Melanium Ging. section) - Looking for unique, adaptive microstructural floral, and embryological characters. Plant Biosystems , 151(6) , 1022-1034.

Słomka A., Libik-Konieczny M., Kuta E., Miszalski Z. (2008) Metalliferous and non-metalliferous populations of Viola tricolorrepresent similar mode of antioxidative response. Journal of Plant Physiology , 165 , 16101619 .

Słomka A., Sutkowska A., Szczepaniak M., Malec P., Mitka J., Kuta E. (2011) Increased genetic diversity of Viola tricolor L. (Violaceae) in metal-polluted environments. Chemosphere ,83 , 435-442.

Słomka A., Żabicka J., Shuka L., Bohdanowicz J., Kuta E. (2018) Lack of correlation between pollen aperture number and environmental factors in pansies (Viola L., sect. Melanium Ging.) - pollen heteromorphism re-examined. Plant Biology, $20,555-562$.

Sperotto R.A., Ricachenevsky F.K., Williams L.E., Vasconcelos M.W., Menguer P.K.

(2014) From soil to seed: micronutrient movement into and within the plant. Frontiers in Plant

Science, 5(438), 1-3.

Sun K., Hunt K., Hauser B.A. (2004) Ovule Abortion in Arabidopsis Triggered by Stress. Plant Physiology , $135,2358-2367$.

Szarek-Łukaszewska G, Niklińska M. (2002) Concentration of Alkaline and Heavy Metals in Biscutella laevigata L. and Plantago lanceolata L. Growing on Calamine Spoils (S Poland). Acta Biologica Cracoviensia Series Botanica , 44, 29-38.

Tremetsberger K., König C., Samuel R., Pinsker W., Stuessy T.F. (2002) Intraspecific genetic variation in Biscutella laevigata (Brassicaceae): new focus on Irene Manton's hypothesis. 
Plant Systematics and Evolution, 233 , 163-181.

Wasowicz P., Pielichowska M., Przedpełska-Wasowicz E., Bednarek P., Szarek-Łukaszewska G., Abratowska A., Wierzbicka M. (2014) Physiological and genetic differentiation between metallicolous and nonmetallicolous diploid populations of alpine Biscutella laevigata(Brassicaceae) in the Tatra Mountains and the northern Carpathian foreland. Annales Botanici Fennici , 51 , 227-231.

Wierzbicka M., Pielichowska M. (2004) Adaptation of Biscutella laevigata L., a metal hyperaccumulator, to growth on zinc-lead waste heap in southern Poland. I: Differences between waste-heap and mountain populations. Chemosphere, 54, 1663-1674.

Wierzbicka M., Pielichowska M., Bemowska-Kałabun O., Wasowicz, P. (2017) Microevolution on Anthropogenically Changed Areas on the Example ofBiscutella laevigata Plants from Calamine Waste Heap in Poland.Journal of Environmental and Analytical Toxicology7(471), doi: 10.4172/2161-0525.1000471.

Wierzbicka M., Rostański A. (2002) Microevolutionary changes in ecotypes of calamine waste heap vegetation near Olkusz, Poland: A Review.Acta Biologica Cracoviensia Series Botanica , 44 , 7-19.

Walker E.L., Waters B.M. (2011) The role of transition metal homeostasis in plant seed development. Current Opinion of Plant Biology ,14, 318-324.

Young B.A., Sherwood R.T., Bashaw E.C. (1979) Cleared-pistil and thick-sectioning techniques for detecting aposporous apomixis in grasses. Canadian Journal of Botany , 57, 1668-1672.

Young A.G., Broadhurst L.M., Thrall P.H. (2012) Non-additive effects of pollen limitation and selfincompatibility reduce plant reproductive success and population viability. Annals of Botany , 109, 643-653.

Zinn K.E., Tunc-Ozdemir M., Jeffrey F., Harper J.F. (2010) Temperature stress and plant sexual reproduction: uncovering the weakest links. Journal of Experimental Botany , 61(7) , 1959-1968.

Tables

Table 1. Frequency of analyzed embryological processes in anthers of B. laevigata from calamine and mountain populations

\begin{tabular}{|c|c|c|c|}
\hline & Calamine population & Mountain population & Statistic chi square test \\
\hline $\begin{array}{l}\text { Degenerations in anthers } \\
\text { during development }\end{array}$ & $39.4 \% 71 / 28^{\mathrm{a}}$ & $19.2 \% 52 / 10$ & $\begin{array}{l}\mathrm{N}=123 ; \chi^{2}=5.74 \\
0.02<\mathrm{P}<0.01^{*}\end{array}$ \\
\hline Viability of pollen grains & $87 \pm 4 \% 2280 / 1937^{\mathrm{b}}$ & $98 \pm 0.7 \% 2010 / 1966$ & $\begin{array}{l}\mathrm{N}=4290 ; \chi^{2}=215.08 \\
\mathrm{P}<0.001^{*}\end{array}$ \\
\hline $\begin{array}{l}{ }^{a} \text { Number of all } \\
\text { analyzed flower }\end{array}$ & $\begin{array}{l}{ }^{a} \text { Number of all } \\
\text { analyzed flower }\end{array}$ & $\begin{array}{l}{ }^{a} \text { Number of all } \\
\text { analyzed flower }\end{array}$ & $\begin{array}{l}\text { a Number of all } \\
\text { analyzed flower }\end{array}$ \\
\hline bud/number of anthers & bud/number of anthers & bud/number of anthers & bud/number of anthers \\
\hline with disturbances, & with disturbances, & with disturbances, & with disturbances, \\
\hline${ }^{\mathrm{b}}$ Number of all pollen & ${ }^{\mathrm{b}}$ Number of all pollen & ${ }^{\mathrm{b}}$ Number of all pollen & ${ }^{\mathrm{b}}$ Number of all pollen \\
\hline grains/number of & grains/number of & grains/number of & grains/number of \\
\hline viable pollen & viable pollen & viable pollen & viable pollen \\
\hline grains, ${ }^{*}$-statistically & grains, ${ }^{*}$-statistically & grains, ${ }^{*}$-statistically & grains, ${ }^{*}$-statistically \\
\hline significant difference & significant difference & significant difference & significant difference \\
\hline
\end{tabular}

Table 2. Frequency of analyzed embryological processes in ovules of B. laevigata from calamine and mountain populations 


\begin{tabular}{|c|c|c|c|}
\hline & Calamine population & Mountain population & Statistic chi square test \\
\hline $\begin{array}{l}\text { Developing additional } \\
\text { embryo sac in an ovule }\end{array}$ & $7.1 \% 254 / 18$ & $8.2 \% 239 / 19$ & $\begin{array}{l}\mathrm{N}=493 ; \chi^{2}=0.13 \\
0.9<\mathrm{P}<0.5\end{array}$ \\
\hline $\begin{array}{l}\text { Degenerations during } \\
\text { megasporogenesis and } \\
\text { megagametogenesis }\end{array}$ & $14.0 \% 236 / 33$ & $7.3 \% 220 / 16$ & $\begin{array}{l}\mathrm{N}=456 ; \chi^{2}=5.35 \\
0.05<\mathrm{P}<0.02^{*}\end{array}$ \\
\hline Shortened embryo sac & $25.5 \% 141 / 36$ & $3.8 \% 146 / 6$ & $\begin{array}{l}\mathrm{N}=287 ; \chi^{2}=26.35 \\
\mathrm{P}<0.001^{*}\end{array}$ \\
\hline $\begin{array}{l}\text { Aging embryo sac } \\
\text { without fertilization }\end{array}$ & $9.9 \% 141 / 14$ & $6.8 \% 146 / 10$ & $\begin{array}{l}\mathrm{N}=287 ; \chi^{2}=0.89 \\
0.3<\mathrm{P}<0.5\end{array}$ \\
\hline $\begin{array}{l}\text { Degenerations during } \\
\text { embryogenesis }\end{array}$ & $15.5 \% 45 / 7$ & $5.3 \% 38 / 2$ & $\begin{array}{l}\mathrm{N}=83 ; \chi^{2}=2.11 \\
0.2<\mathrm{P}<0.1^{* *}\end{array}$ \\
\hline $\begin{array}{l}\text { Degenerations of flower } \\
\text { buds, flowers, ovules }\end{array}$ & $5.9 \% 339 / 40$ & $6.6 \% 318 / 41$ & $\begin{array}{l}\mathrm{N}=657 ; \chi^{2}=0.18 \\
0.3<\mathrm{P}<0.5\end{array}$ \\
\hline $\begin{array}{l}\text { Number of all analyzed } \\
\text { ovules/numbers of } \\
\text { analyzed stages, } \\
\text { *-statistically } \\
\text { significant difference, } \\
\text { **- insufficient number } \\
\text { of analyzed ovules }\end{array}$ & $\begin{array}{l}\text { Number of all analyzed } \\
\text { ovules/numbers of } \\
\text { analyzed stages, } \\
\text { *-statistically } \\
\text { significant difference, } \\
\text { **- insufficient number } \\
\text { of analyzed ovules }\end{array}$ & $\begin{array}{l}\text { Number of all analyzed } \\
\text { ovules/numbers of } \\
\text { analyzed stages, } \\
\text { *-statistically } \\
\text { significant difference, } \\
\text { **- insufficient number } \\
\text { of analyzed ovules }\end{array}$ & $\begin{array}{l}\text { Number of all analyzed } \\
\text { ovules/numbers of } \\
\text { analyzed stages, } \\
\text { *-statistically } \\
\text { significant difference, } \\
\text { **- insufficient number } \\
\text { of analyzed ovules }\end{array}$ \\
\hline
\end{tabular}

Table 3. Frequency of analyzed siliculas of B. laevigata from calamine and mountain populations

\begin{tabular}{|c|c|c|c|}
\hline & Calamine population & Mountain population & Statistic chi square test \\
\hline $\begin{array}{l}\text { Percentage of two-seeds } \\
\text { siliculas }\end{array}$ & $55.0 \% 240 / 132$ & $40.7 \% 113 / 46$ & $\begin{array}{l}\mathrm{N}=353 ; \chi^{2}=22.47 \\
\mathrm{P}<0.001^{*}\end{array}$ \\
\hline $\begin{array}{l}\text { Percentage of one-seed } \\
\text { siliculas }\end{array}$ & $29.6 \% 240 / 71$ & $21.2 \% 113 / 24$ & \\
\hline $\begin{array}{l}\text { Percentage of empty } \\
\text { siliculas }\end{array}$ & $15.4 \% 240 / 37$ & $38.1 \% 113 / 43$ & \\
\hline $\begin{array}{l}\text { Number of all analyzed } \\
\text { siliculas/numbers of } \\
\text { analyzed stages, } \\
\text { *-statistically } \\
\text { significant difference, }\end{array}$ & $\begin{array}{l}\text { Number of all analyzed } \\
\text { siliculas/numbers of } \\
\text { analyzed stages, } \\
\text { *-statistically } \\
\text { significant difference, }\end{array}$ & $\begin{array}{l}\text { Number of all analyzed } \\
\text { siliculas/numbers of } \\
\text { analyzed stages, } \\
\text { *-statistically } \\
\text { significant difference, }\end{array}$ & $\begin{array}{l}\text { Number of all analyzed } \\
\text { siliculas/numbers of } \\
\text { analyzed stages, } \\
\text { *-statistically } \\
\text { significant difference, }\end{array}$ \\
\hline
\end{tabular}

\section{Figure captions}

Fig.1. Male and female developmental lineages from specimens growing in the Tatra Mts., mountain population: (a) pollen mother cells and tapetum surrounded anther locules; (b) anther locules filled with normal pollen grains, 3-celled pollen inserted; (c) megaspore mother cell; (d) telophase II in diad; (e) 1-nucleate embryo sac at chalazal pole, 3 degenerating megaspores (arrow) at micropylar pole; (f) mature embryo sac with egg cell, one visible synergid at micropylar pole and central cell with secondary nucleus; $(\mathrm{g})$ embryo with cotyledons, hypocotyl, radicle, surrounded by cellular endosperm; (h) chalazal and subchalazal megaspores of the tetrad enlarged, developing in two embryo sacs, two degenerating megaspores at micropylar pole (arrow); (i) two embryo sacs in one ovule: mature ESI, visible secondary nucleus of central cell, mature ESII, egg cell, one synergid and outline of secondary nucleus (arrow) visible. pmc - pollen mother cell; t tapetum; pg - pollen grains; e- epidermis of nucellus; mc - megaspore mother cell; ii - inner integument; 
oi - outher integument D - diad; ES - embryo sac; ec - egg cell; s - synergid; sn - secondary nucleus; c cotyledon; $\mathrm{h}$ - hypocotyl; $\mathrm{r}$ - radicle; ce - cellular endosperm. Bars: $20 \mu \mathrm{m}$ in (a,f,h,i); $10 \mu \mathrm{m}$ in (c,d,e); 100 $\mu \mathrm{m}$ in (b); $200 \mu \mathrm{m}$ in (g).

Fig. 2. Male and female developmental lineages, degenerations, metal detection in plants from Bolesław, calamine population: (a) anther locules at tetrad stage, visible degenerated tetrads (arrows) and tapetum surrounding locules; (b) normal and degenerated microspores (arrows); (c) degenerated tapetal cells and microspores (arrow); (d) mature pollen grains, degenerating (empty) pollen (arrows); (e, f) shortened embryo sacs, viable (e) and degenerated (f); (g) unfertilized, aging embryo sac, visible egg cell and secondary nucleus of the central cell visible; (h) degenerated cells of the stigma (arrows); (i,k) empty silicula with degenerated ovules/seeds (arrows); (j) normal silicula with two seeds; (i) one-seed silicula; (m, n) flowers (m) and one-seed silicula (n) after dithizone staining. Red color indicates the presence of metals. $\mathrm{T}$ - tetrad of microspores; t - tapetum; $\mathrm{m}$ - microspores; pg - pollen grains; ES - embryo sac; ec - egg cell; sn - secondary nucleus; Bars: $10 \mu \mathrm{m}$ in (a); $100 \mu \mathrm{m}$ in (d,h); $20 \mu \mathrm{m}$ in (b,c,e-g); $200 \mu \mathrm{m}$ in (i); $2 \mathrm{~mm}$ in (j-n).

Fig. 3. Immunohistochemical localization of pectic epitopes recognized by LM19 and LM20 antibodies in cell walls of mature embryos from seeds of plants from the Tatra Mts., mountain population and Bolesław, calamine population. Arrows indicate localization of epitopes: (a-c) pectic epitope recognized by LM19 antibody, indicating un-low-esterified HG, distributed uniformly in all cell walls of cotyledons of mountain population embryo (a) and calamine population (b), in hypocotyl of calamine population embryo (c); (d-f) pectic epitope recognized by LM 20 antibody, indicating high-esterified HG, not detected in any cell walls of mountain population embryo (d), and distributed in spots in cell walls of cotyledons (e) and hypocotyls (f) of calamine population embryo. Bars: $50 \mu \mathrm{m}$ in (a-f). 

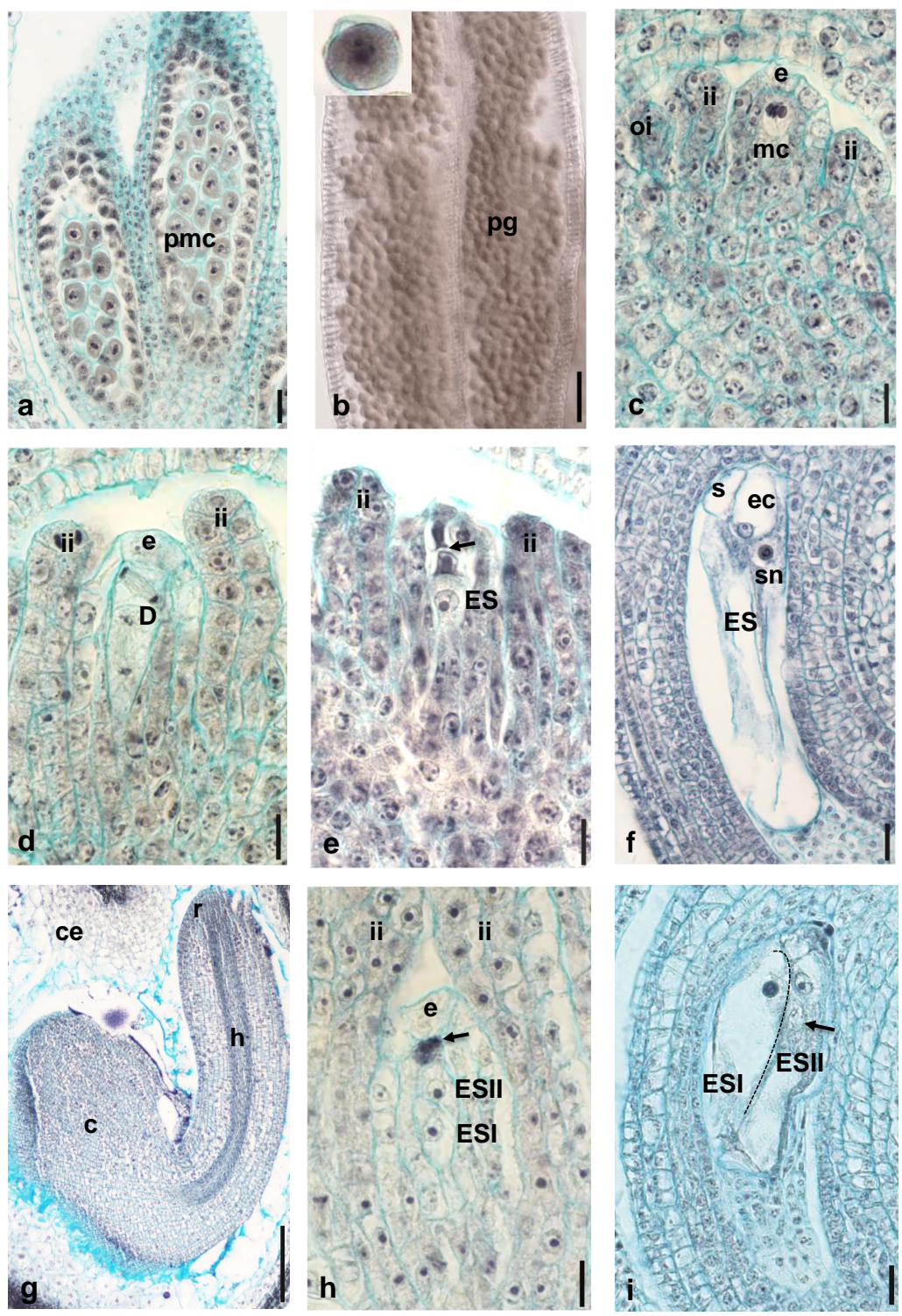


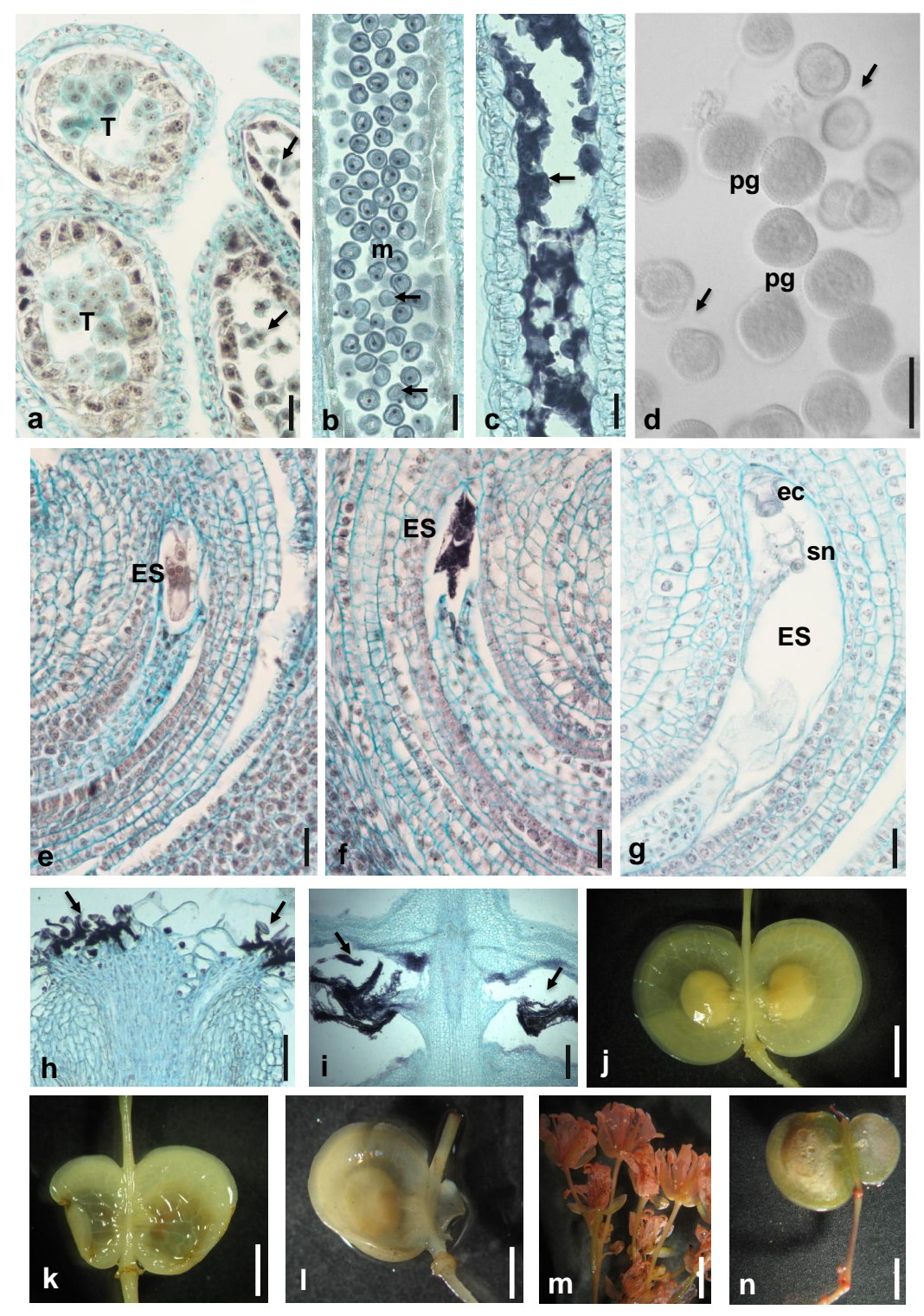



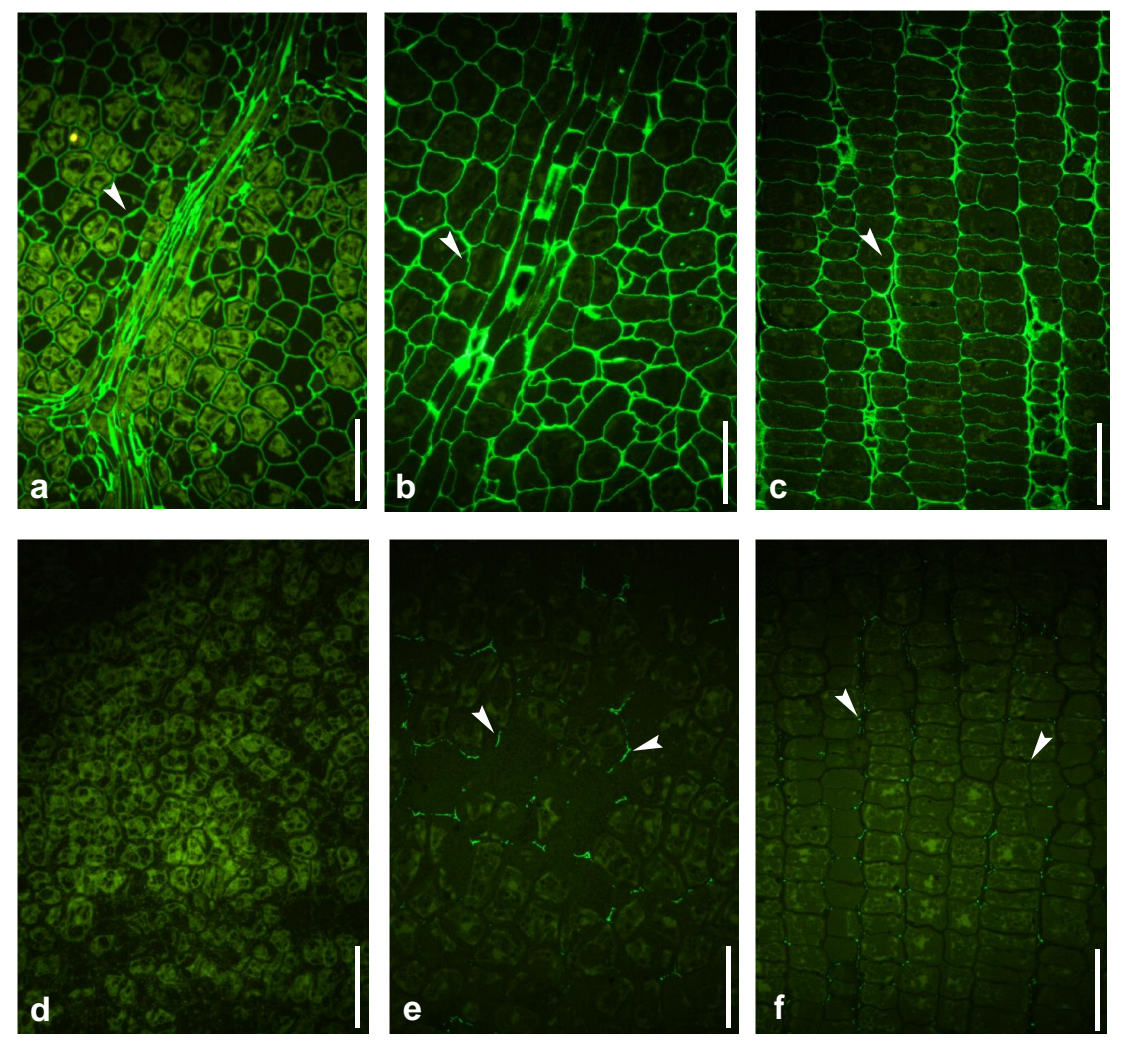